\title{
A study on earthquake performances of reinforced concrete buildings with various number of stories
}

\author{
Yuşa Uğur Çapa iD, Ali Ruzi Özuygur* iD, Zekai Celep \\ Fatih Sultan Mehmet Vakif University, Department of Civil Engineering, Istanbul, Turkey
}

\begin{abstract}
Seismic codes generally require that the Equivalent Seismic Load Method or the Modal Response Spectrum Method is adopted in the design of buildings. In the equivalent seismic load method, the equivalent seismic static force applied to the building is determined depending on the seismicity of the region where the building is located, the usage class of the building, the fundamental period of the building and the building mass. Later, this equivalent seismic load is reduced by the seismic load reduction factor to take into account the increase in the capacity of the system and the decrease in the seismic demand due to the nonlinear and inelastic behavior of the system, i.e., by accepting limited inelastic deformations in the building subjected to the design earthquake. Then, structural system of the building is analyzed under the reduced seismic forces in addition to the vertical loads by using the load combinations given in the design codes. The process is completed by designing the sections and the structural elements of the building. Similar processes can be implemented by using the modal response spectrum method. The difference between these two methods is consideration of the higher modes of the building instead of the first mode only and the use of the modal masses of the building for each mode, instead of the total mass of the building. In the latter method, the contributions of the higher mode are combined by using specific superposition rules. The codes assume that the structural systems designed in this way will exhibit the almost same level of inelastic deformation, i.e., the controlled damage state, regardless of the building parameters, such as the number of stories. In this study, an attempt is made to investigate the validity of this implicit acceptance. For this purpose, the buildings with a various number of stories are designed by satisfying the bare minimum requirements of the code only, as much as possible. The seismic behavior and the lateral load capacity of these buildings are examined by the static and dynamic nonlinear analyses. The ratio of the nonlinear load capacity to the reduced equivalent seismic load is evaluated depending on the number of the stories of the buildings. The results which are presented in detail yield that the buildings with a low number of stories have relatively larger nonlinear lateral load capacity-to-the reduced elastic seismic load ratio, which is not compatible with the general implicit assumption made in the seismic codes.
\end{abstract}

\section{Keywords}

Design of buildings; Reinforced concrete buildings; Linear analysis; Nonlinear analysis; Static pushover; Nonlinear time-domain analysis; Performance-based design

Received: 20 March 2021; Accepted: 24 April 2021

ISSN: 2630-5763 (online) C 2021 Golden Light Publishing All rights reserved.

\section{Introduction}

Design of buildings in seismic prone regions is carried out by following the requirements of the seismic codes and the design codes developed for

\footnotetext{
* Corresponding author

Email: aliruzi@gmail.com
} 
the structural systems, such as concrete and steel structures. Almost every country has its own seismic code as well as its design code. When the seismic codes are examined in detail, it is seen easily that the most codes have similar analysis and design methods, however inherently they contain differences in some details, depending on the construction practices of the country, including minimum requirements. With the developments in structural analysis and the lessons learned from the past earthquakes, the codes are modified steadily [1]. It is generally assumed that the buildings, designed according to the requirements of the codes, exhibit nonlinear response, i.e., controlled damage state, when they are subjected to design earthquake which can be considered a medium-high intensity earthquake. Non-linear analyses originally developed for plane frames provide to the designers to check the structural system and generate at the same time a wide range of modeling alternatives [2]. Pushover curves which represent nonlinear static behavior of the structural systems under lateral load illustrate the damage state and are used to check whether they are with the limits [3]. However, the extension of pushover analysis to irregular buildings is not straightforward and has some drawbacks, because each structural element different nonlinear behavior, such as beams and columns and frame and shear walls. Almost every code has its specific limits depending on their structural properties developed in its region. Since the pushover analysis highly nonlinear, in some cases, a small change in the system geometry or the concrete sections and the reinforcement area may lead to very different results. Being aware of this difficulty, ways of simplification of the nonlinear analysis are sought in some studies [4]. However, although some results are obtained for regular structural geometry, the problems persist for the structural system having irregularities. For these reasons, various advanced pushover models have been developed for providing robustness to the nonlinear process and for the fast solution to be used for moment-resisting frame structures as well as for dual shear wall-frame structures [5]. The dual wall-frame structures display present different difficulties because of the strong structural interaction between these two structural systems. The nonlinear behavior of the two shear walls is investigated to obtain the fast prediction of the seismic demand by using the pushover analysis [6]. Shear walls are modeled by adopting a multi-layershell element and it is shown that the numerical solution can have certain robustness. It is worth noting that the problem has certain symmetry and simplicity. However, the effects of nonlinearity will be more complex in the presence of a large number of shear walls, frames, and structural irregularity. Effects of soil, confinement reinforcement and concrete strength on nonlinear static dynamic timedomain analyses are investigated by adopting plastic hinge model [7, 8]. Results show that soil class has a profound effect on the seismic behavior of buildings and confinement reinforcement increases building lateral load capacity and decreases rotations at the structural elements. Seismic load reduction factor which connects the nonlinear behavior of the structural system with the linear one is studied by considering steel momentresisting frames and taking into account nonlinear static and response-history analysis and inelastic demands over the building height and ductility demands are obtained comparatively with the design assumptions [9].

Most building seismic codes recognize the static equivalent lateral force method essential for the design of many low-rise regular structures, where the first mode is assumed to be dominant in the seismic behavior. For buildings having relatively long fundamental periods, the modal response spectrum method is recommended where the contributions of the higher modes are taken into account. The linear time-domain analysis is a relatively more sophisticated method that requires the use of the acceleration records that are compatible with the design spectrum. In these methods where the linear analysis is adopted and the nonlinear behavior of the structural system, i.e., the increase in the capacity of the system and the decrease in the demand of the earthquake, is taken into account by employing the earthquake load reduction coefficient, in other words, the response 
modification factor [10]. On the other hand, the nonlinear behavior of the structural system can be taken into account directly, by analyzing the system considering nonlinear deformations. In fact, the response modification factor is an important parameter that reflects the energy dissipating capability of the structures. Seismic codes assume that structure systems conforming to the requirements of the codes can sustain large inelastic deformation without reaching the total collapse and dissipate a large amount of seismic energy. Response modification factors of seismic codes are based primarily on observations and comparison of the structural systems subjected to strong earthquakes.

The pushover analysis and the nonlinear timedomain analysis can be assumed as an extension of the static equivalent lateral load analysis and the linear time-domain analysis, respectively. In general, analysis of the structural system can be accomplished by taking into account distributed inelastic deformations in the regions where deformations exceed beyond the elastic limit. However, the use of plastic hinges can be employed relatively easily in the frame-type structural systems, including in the slender shear walls. Since the nonlinear analysis yields the lateral load capacity of the system directly within the inherent assumptions, there is no need to use the response modification coefficient. Consequently, the response modification coefficients can be evaluated by comparing the lateral load capacities of the nonlinear and the linear analyses. However, assumptions of the nonlinear analysis cover only limited nonlinearity, for this reason, the response modification factors evaluated in this way for the structural systems are always lower than those specified by the codes. Nevertheless, this analysis can be used for comparison, as it is done in the present study.

Melani et al. [11] studied the nonlinear behavior of mid-rise reinforced concrete frame buildings by nonlinear time-domain analysis employing the performance parameters such as maximum interstory drift ratios and fragility curves. Uva et al. [12] concluded that the capacity of structural systems (in terms of displacement at Life Safety Limit State) with reference to several cases of existing $\mathrm{RC}$ buildings can be strongly affected by the choice of the control node position. In order to optimize the choice procedure of control node, a parametric formulation is proposed, depending on geometric features, able to estimate the variability of the capacity curve at the variation of control node position. Salimbahrami and Gholhaki [13] investigated the strength reduction factor-related closely to ductility and the modification factor representing the ratio of inelastic to elastic displacement in single degree of freedom systems subjected to horizontal and vertical components of near and far-field earthquakes. The results indicate that the strength reduction factor displays a variation depending on the near and far-field ground motions. In addition, the modification factor does not depend on characteristics of ground motion and is converged to the unity as the period of the system increases. Lu, Hajirasouliha and Marshall [14] performed a parametric analysis to study the strength-ductility relationship of buildings with different fundamental periods by focusing on soil-structure interaction. The results indicate that the modification factor is mainly affected by the structure to soil stiffness ratio, fundamental period and slenderness ratio of the building, but it is not sensitive to the variation of ductility demand and number of stories. Rao and Gupta [15] investigated the effect of the seismic zone and story height on response reduction factor and interpreted the numerical results. They concluded that overstrength and ductility factors vary with the number of stories and seismic zones.

Harmonization of the codes also occurs by interacting with each other by adopting generally accepted requirements. The present study uses the requirements in the Turkish Seismic Code for Buildings of 2018 [16] in the analysis and design. However, this code is closely related to the ASCE 7-16 [17] in terms of the main requirements; consequently, the conclusions drawn in the present study can be accepted to be valid in the case of the other codes as well. 
The seismic codes assume that the structural systems designed by using the linear methods, i.e., the static equivalent lateral force method, the modal response spectrum method and the time domain analysis, by adopting a response modification factor, exhibit the same level of inelastic deformations. In other words, the response modification factor depends on the structural systems only, i.e., whether it is a moment-resisting frame system, a shear wall system or a hybrid system, as it is given in Table 12.2-1 of ASCE 7-16 [17]. In other words, the codes assume that the response modification factors depend on the seismic resisting systems solely, but on no other parameters of the structural system, including the number of stories.

The objective of the present study is to investigate the dependency of the response modification coefficient, i.e. the seismic load reduction factor on the number of stories of buildings. For this purpose, the buildings having moment-resisting frame structural systems with a various number of stories are designed by satisfying the bare minimum requirements of the code in order not to produce an additional overstrength factor. As known, the overstrength factor comes into being mostly due to participation of nonstructural elements, minimum requirements for the geometry of the structural members, minimum reinforcement ratios, minimum and available reinforcements and their arrangements, participation of slabs, structural drift considerations. The nonlinear lateral load capacity of the systems is investigated by applying the pushover analysis and the nonlinear timedomain analysis. The ratio of the nonlinear load capacity to the reduced equivalent seismic load is evaluated depending on the number of the stories of the buildings and the ratio is considered to be a parameter directly related to the response modification factor, i.e. the seismic load reduction factor. The numerical results are presented in tables and figures which are discussed in detail. In the numerical study, the requirements of the Turkish Seismic Code for Buildings of 2018 [16] are adopted. Nevertheless, the conclusions can be accepted to be valid generally, because the numerical results are presented in terms of nondimensional parameters and the Turkish Seismic Code for Buildings is closely related to the ASCE 7-16 [17] in terms of the main requirements. Since linear and nonlinear performances of the structural systems are studied comparatively, the contribution of masonry infill walls is not considered. Since the number of stories is the parameter studied, momentresisting frame systems are chosen to be simple and symmetrical in the two directions.

\section{Structural systems of the selected buildings for the numerical study}

To study the relationship between the response modification coefficient and the number of stories of the building, three moment-resisting frame systems are designed by satisfying the requirements of the Turkish Seismic Code for Buildings of 2018 which is closely related to the ASCE 7-16. The selected buildings have the similar structural configuration and geometry. The structures are assumed to be located in Istanbul, a region of high seismicity. The corresponding acceleration coefficients for the short period SS $=0.968 \mathrm{~g}$ (SDS $=1.162 \mathrm{~g}$ including site soil class modification factor) and the spectral coefficient (for the period for $1 \mathrm{sec}) \mathrm{S} 1=0.268 \mathrm{~g}$ ( $\mathrm{SD} 1=0.402 \mathrm{~g}$ including site soil class modification factor) are assumed for the design earthquake. Furthermore, the building importance factor $I=1$, the live load mass participation factor $n=0.30$ (residence), the site soil class ZC, concrete class $\mathrm{C} 30 / 37$ and reinforcing steel class B420C are adopted.

In the design of the buildings, the static equivalent lateral force method is used and the response modification factor is assumed to be $R=8$ by considering that the structural system is a moment-resisting frame. The buildings of three, five and seven stories are chosen. Fig. 1 shows layout and elevation views of the frame structures which have symmetry and three bays in each direction. The slab thickness is assumed to be 120 $\mathrm{mm}$, a floor finish load of $1.50 \mathrm{kN} / \mathrm{m}^{2}$ and a live load of $2.00 \mathrm{kN} / \mathrm{m}^{2}$ are considered. Additionally, a line load of $6.25 \mathrm{kN} / \mathrm{m}$ is adopted to represent the weight of the partition walls on the floors. 


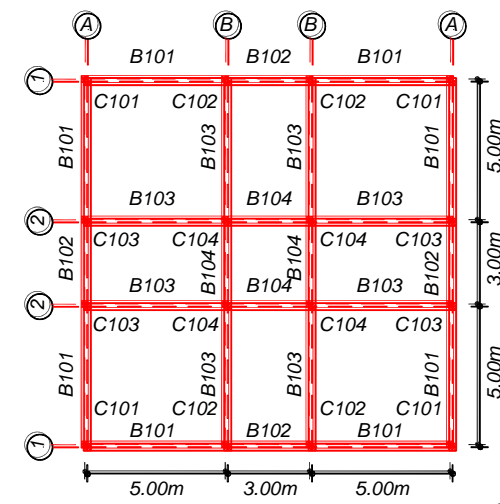

Building B3

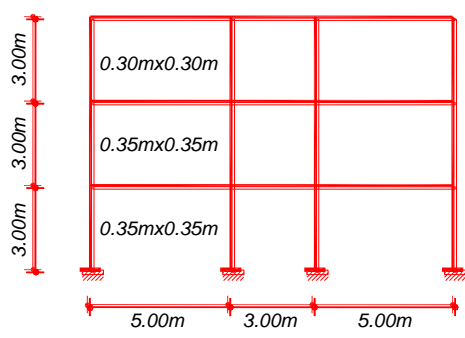

Beams

$0.25 \mathrm{~m} / 0.50 \mathrm{~m}$

Slabs

(a) Layout of the buildings

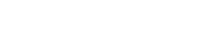

(b) Elevations of the buildings and sections of the columns

Building B5

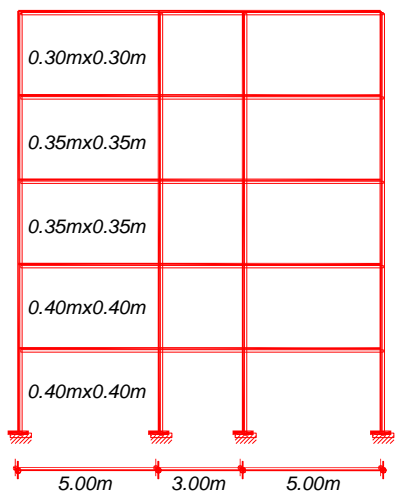

Building B7

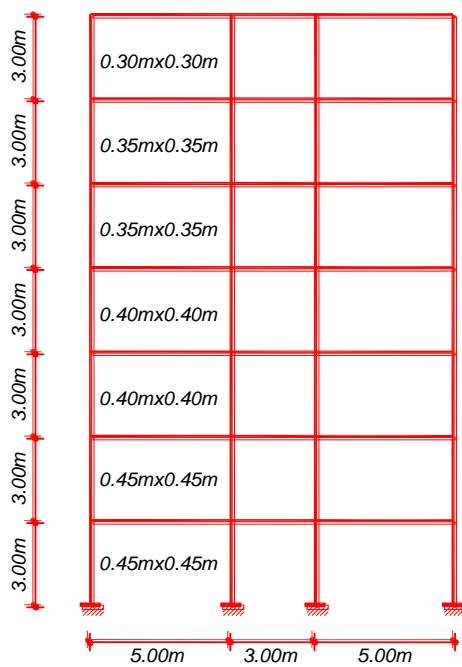

Fig. 1. Layout and elevation of the structural systems of the buildings

\section{Linear static and dynamic analysis and design of the buildings}

Analysis and design of the structural systems are accomplished by employing SAP2000 software by following the static equivalent lateral force method [18]. The procedure is applied by paying attention to that the bare minimum requirements of the code without exceeding them unnecessarily, so that structural systems of the minimum sizes and reinforcements are obtained. To accomplish this requirement, the design procedure is repeated several times, in other words, an iteration procedure is implemented on the sizes and the reinforcements of the structural elements.

Analysis and design of the buildings are carried out by considering vertical and seismic loads by using the well-known load combinations. Their characteristic results are given in Table 1, including the period, the seismic base shear and the lateral displacement for each building. Furthermore, the related characteristic results obtained by employing the modal response spectrum analysis are presented in Table 2. In the numerical presentation, the shear forces are reduced by the response modification factor; however the lateral displacements and interstory drift ratios correspond to the elastic values, i.e., no reduction is applied as expected, to represent the nonlinear demand as well.

The buildings are analyzed by using the time domain procedure as well. For this purpose, three ground motions are selected by scaling the 5\% damped response spectra to be compatible with the design spectrum. The Pacific Earthquake Engineering Research (PEER) Center, NGA strong motion database is used for this study and scaling is accomplished by using SeismoMatch software [19, 20]. The selected acceleration records are Imperial Valley, California 1979, El Mayor, Mexico 2010 and Darfield, New Zealand 2010 with the scaling factors of 2.143, 1.029 and 3.153, respectively. Their time-acceleration histories are shown in Fig. 2 in the scaled form. Furthermore, the elastic response spectra of the scaled records and the selected design spectrum are presented in Fig. 3. 
Table 1. Numerical results of the static equivalent lateral force method

\begin{tabular}{ccccccccc}
\hline Building & $\begin{array}{c}\text { Weight } \\
(\mathrm{kN})\end{array}$ & $\begin{array}{c}\text { Period } \\
(\mathrm{s})\end{array}$ & $\begin{array}{c}\text { Elastic spectral } \\
\text { acceleration }(\mathrm{g})\end{array}$ & $\begin{array}{c}\text { Base shear } \\
(\mathrm{kN})\end{array}$ & $\begin{array}{c}\text { Base } \\
\text { shear } \\
/ \text { Weight }\end{array}$ & $\begin{array}{c}\text { Minimum } \\
\text { base shear } \\
(\mathrm{kN})\end{array}$ & $\begin{array}{c}\text { Lateral } \\
\text { displacement } \\
(\mathrm{mm})\end{array}$ & $\begin{array}{c}\text { Total drift } \\
\text { ratio } \\
(\%)\end{array}$ \\
\hline B3 & 5919 & 0.51 & 0.790 & 584 & 0.0987 & 275 & 68.0 & 0.756 \\
B5 & 9981 & 0.67 & 0.601 & 749 & 0.0750 & 463 & 98.4 & 0.656 \\
B7 & 13993 & 0.90 & 0.481 & 839 & 0.0600 & 650 & 160.0 & 0.762 \\
\hline
\end{tabular}

Table 2. Numerical results of the modal response spectrum method

\begin{tabular}{ccccc}
\hline Building & Base shear $(\mathrm{kN})$ & Base shear/Weight & Lateral displacement $(\mathrm{mm})$ & Total drift ratio $(\%)$ \\
\hline B3 & 498 & 0.0841 & 69.6 & 0.773 \\
B5 & 643 & 0.0644 & 81.1 & 0.541 \\
B7 & 718 & 0.0513 & 127.3 & 0.606 \\
\hline
\end{tabular}
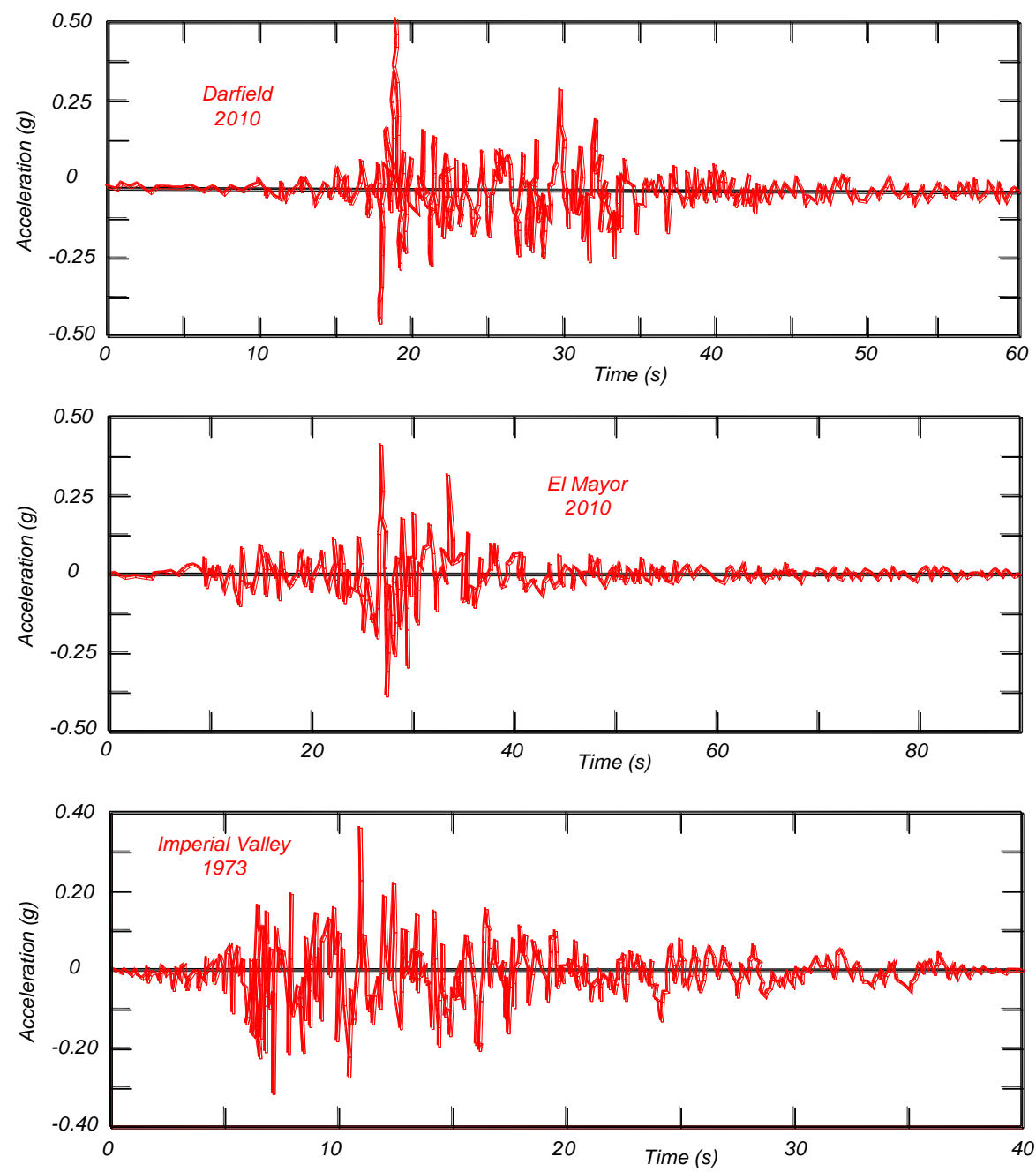

Fig. 2. Time-acceleration record of the selected earthquakes 


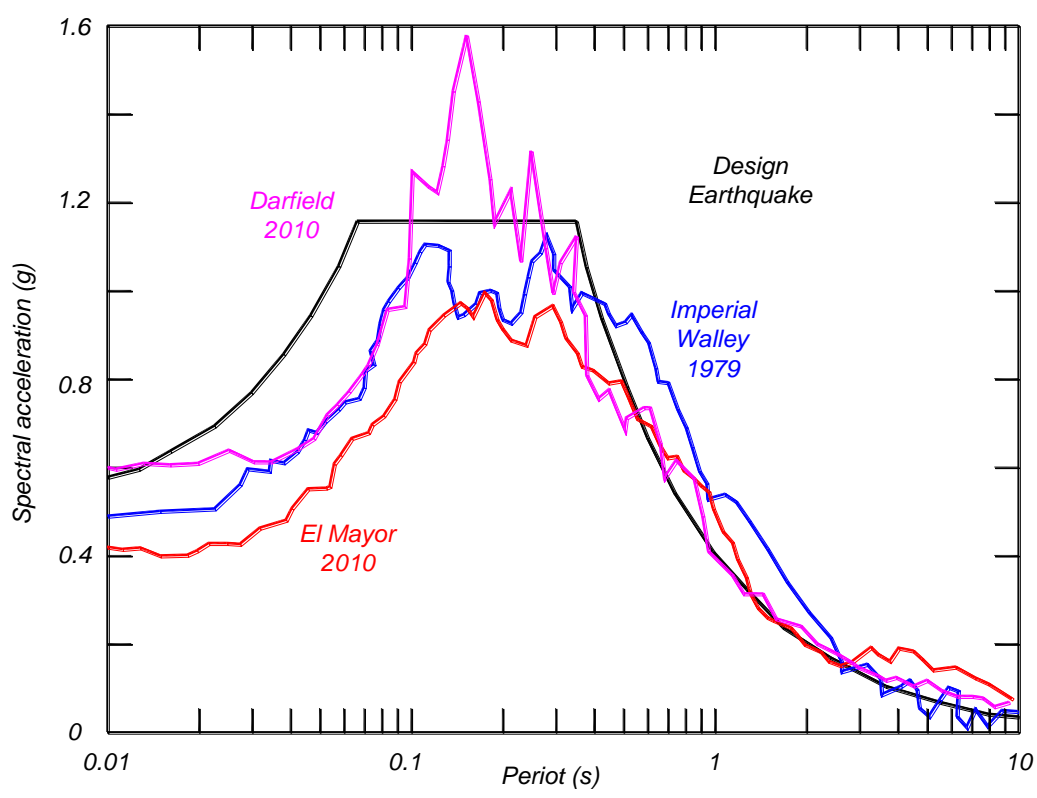

Fig. 3. Elastic response spectra of the selected earthquakes and that of the design earthquake

The corresponding characteristic results of the time domain analysis are presented in Table 3 . When the results of the linear analyzes given in Table 1-3 are inspected, the compatibility of the results can be seen easily. As expected, the equivalent lateral force method produces the largest base shear, the results of the modal response spectrum analysis are, in general, lower than those of the equivalent lateral force procedure. On the other hand, although the acceleration records of the time domain analysis are scaled to achieve compatibility with the selected design spectrum, the results display wide scattering and appear to be significantly dependent on the record itself and yield significant difference with those of the equivalent lateral force procedure. The reason why the codes require that a large number of records has to be considered in the design supports this conclusion. The most important reason for the scattering of the numerical results is the uneven variation of the spectra of the selected ground motions, whereas the design spectrum displays very smooth variation. Design of the concrete members of the buildings is carried out by taking into account the vertical loads and the seismic load using equivalent lateral force procedure and the wellknown principles of the ultimate design method. Configuration of the beams of the first floor is shown in Fig. 1a and the sizes and reinforced details of the beams and the columns are presented in Table 4-6 and Table 7-9, respectively. As these tables show, the reinforcement of the beams in the building displays variation between the stories, whereas their geometry remains the same. On the other hand, the geometry and reinforcement of the columns exhibit variations between stories. As an example, the beam B504 in Table 5 is located on the fifth story of the five-story building as shown in Fig. 1a. On the other hand, the column CA5 in Table 8 is found on the first and second stories of the five-story building. It is located at the intersection point of axes A and 5 as shown in Fig. 1a.

\section{Nonlinear static analysis of the buildings}

Nonlinear static (pushover) analysis is employed to evaluate the lateral seismic inelastic capacity of the buildings designed by using the equivalent lateral force procedure. The analysis is carried out by adopting the plastic hinge assumption and using SAP2000 software. Plastic hinges of the beams are defined considering moment-curvature relationships, whereas they are defined by considering the effect of the axial force. 
Table 3. Numerical results of the linear time domain analysis

\begin{tabular}{ccccccc}
\hline \multirow{2}{*}{ Building } & $\begin{array}{c}\text { Imperial Valley, California } \\
\text { 1979 (Scaling factor 2.143) }\end{array}$ & \multicolumn{2}{c}{$\begin{array}{c}\text { El Mayor, Mexico 2010 } \\
\text { (Scaling factor 1.029) }\end{array}$} & $\begin{array}{c}\text { Darfield, New Zealand 2010 } \\
\text { (Scaling factor 3.153) }\end{array}$ \\
\cline { 2 - 7 } & $\begin{array}{c}\text { Base } \\
\text { shear/Weight }\end{array}$ & $\begin{array}{c}\text { Total drift } \\
\text { ratio (\%) }\end{array}$ & $\begin{array}{c}\text { Base } \\
\text { shear/Weight }\end{array}$ & $\begin{array}{c}\text { Total drift } \\
\text { ratio (\%) }\end{array}$ & $\begin{array}{c}\text { Base } \\
\text { shear/Weight }\end{array}$ & $\begin{array}{c}\text { Total drift ratio } \\
(\%)\end{array}$ \\
\hline B3 & 0.133 & 1.189 & 0.093 & 0.918 & 0.061 & 0.573 \\
B5 & 0.082 & 0.675 & 0.060 & 0.449 & 0.081 & 0.593 \\
B7 & 0.036 & 0.413 & 0.064 & 0.698 & 0.081 & 0.990 \\
\hline
\end{tabular}

Table 4. Geometry and reinforcement of the beams of the building of three stories

\begin{tabular}{cccccc}
\hline \multirow{2}{*}{ Type } & \multicolumn{2}{c}{ Left support } & \multicolumn{2}{c}{ Right support } & \multirow{2}{*}{ Beams 0.25 m/0.5 0m } \\
\cline { 2 - 4 } & Top & Bottom & Top & Bottom & \\
\hline BA3 & $5 \phi 12$ & $3 \phi 12$ & $5 \phi 12$ & $3 \phi 12$ & B101, B102, B203, B204 \\
BB3 & $6 \phi 12$ & $3 \phi 12$ & $6 \phi 12$ & $3 \phi 12$ & B103, B104 \\
BC3 & $4 \phi 12$ & $3 \phi 12$ & $4 \phi 12$ & $3 \phi 12$ & B201, B202, B304 \\
BD3 & $3 \phi 12$ & $3 \phi 12$ & $3 \phi 12$ & $3 \phi 12$ & B301, B302 \\
BE3 & $4 \phi 12$ & $3 \phi 12$ & $3 \phi 12$ & $3 \phi 12$ & B303 \\
\hline
\end{tabular}

Table 5. Geometry and reinforcement of the beams of the building of five stories

\begin{tabular}{cccccc}
\hline \multirow{2}{*}{ Type } & \multicolumn{2}{c}{ Left support } & \multicolumn{2}{c}{ Right support } & \multirow{2}{*}{ Beams 0.25 m/0.50 m } \\
\cline { 2 - 4 } & Top & Bottom & Top & Bottom & \\
\hline BA5 & $6 \phi 12$ & $3 \phi 12$ & $6 \phi 12$ & $3 \phi 12$ & B101, B201, B203, B204, B303 \\
BB5 & $2 \phi 12+5 \phi 14$ & $4 \phi 12$ & $2 \phi 12+5 \phi 14$ & $4 \phi 12$ & B102, B103, B104, B203, B402, B404 \\
BC5 & $5 \phi 12$ & $3 \phi 12$ & $5 \phi 12$ & $3 \phi 12$ & B202, B301, B302, B304, \\
BD5 & $4 \phi 12$ & $3 \phi 12$ & $4 \phi 12$ & $3 \phi 12$ & B401 \\
BE5 & $3 \phi 12$ & $3 \phi 12$ & $3 \phi 12$ & $3 \phi 12$ & B501, B503, B504 \\
\hline
\end{tabular}

Table 6. Geometry and reinforcement of the beams of the building of seven stories

\begin{tabular}{|c|c|c|c|c|c|}
\hline \multirow{2}{*}{ Type } & \multicolumn{2}{|c|}{ Left support } & \multicolumn{2}{|c|}{ Right support } & \multirow{2}{*}{ Beams $0.25 \mathrm{~m} / 0.50 \mathrm{~m}$} \\
\hline & Top & Bottom & Top & Bottom & \\
\hline BA7 & $5 \phi 12$ & $3 \phi 12$ & $5 \phi 12$ & $3 \phi 12$ & $\begin{array}{l}\text { В101, B102, B201, B202, B301, B302, } \\
\text { B401, B402, B501, B502, B504, B604 }\end{array}$ \\
\hline BB7 & $5 \phi 12$ & $3 \phi 12$ & $5 \phi 12$ & $3 \phi 12$ & $\begin{array}{c}\text { B103, B104, B204, B204, B303, B304, } \\
\text { B403, B404, B503, B603 }\end{array}$ \\
\hline $\mathrm{BC} 7$ & $8 \phi 12$ & $3 \phi 12$ & $5 \phi 12$ & $7 \phi 12$ & B203 \\
\hline BD7 & $4 \phi 12$ & $3 \phi 12$ & $4 \phi 12$ & $3 \phi 12$ & B601, B602, B703, B704 \\
\hline BE7 & $3 \phi 12$ & $3 \phi 12$ & $3 \phi 12$ & $3 \phi 12$ & B701, B702 \\
\hline
\end{tabular}


Table 7. Geometry and reinforcement of the columns of the building of three stories

\begin{tabular}{|c|c|c|c|c|c|}
\hline \multirow{2}{*}{ Type } & \multirow{2}{*}{ Story } & \multirow{2}{*}{ Section } & \multicolumn{2}{|c|}{ Reinforcement } & \multirow{2}{*}{ Configuration } \\
\hline & & & Longitudinal & Lateral & \\
\hline CA3 & 1,2 & $0.35 \mathrm{~m} \times 0.35 \mathrm{~m}$ & $8 \phi 14$ & $\phi 8 / 80$ & D \\
\hline CB3 & 3 & $0.30 \mathrm{~m} \times 0.30 \mathrm{~m}$ & $6 \phi 12$ & $\phi 8 / 80$ & \\
\hline
\end{tabular}

Table 8. Geometry and reinforcement of the columns of the building of five stories

\begin{tabular}{cccccc}
\hline \multirow{2}{*}{ Type } & \multirow{2}{*}{ Story } & Section & \multicolumn{2}{c}{ Reinforcement } & Configuration \\
\cline { 4 - 5 } & & Longitudinal & Lateral & \\
CA5 & 1,2 & $0.40 \mathrm{~m} \times 0.40 \mathrm{~m}$ & $12 \phi 14$ & $\phi 8 / 80$ & \\
CB5 & 3,4 & $0.35 \mathrm{~m} \times 0.35 \mathrm{~m}$ & $8 \phi 14$ & $\phi 8 / 80$ & \\
CC5 & 5 & $0.30 \mathrm{~m} \times 0.30 \mathrm{~m}$ & $6 \phi 14$ & $\phi 8 / 80$ & \\
\hline
\end{tabular}

Table 9. Geometry and reinforcement of the columns of the building of seven stories

\begin{tabular}{cccccc}
\hline \multirow{2}{*}{ Type } & Story & Section & \multicolumn{2}{c}{ Reinforcement } & Configuration \\
\cline { 4 - 5 } & & & Longitudinal & Lateral & \\
CA7 & 1,2 & $0.45 \mathrm{~m} \times 0.45 \mathrm{~m}$ & $16 \phi 14$ & $\phi 8 / 80$ & \\
CB7 & 3,4 & $0.40 \mathrm{~m} \times 0.40 \mathrm{~m}$ & $12 \phi 14$ & $\phi 8 / 80$ & \\
$\mathrm{CC} 7$ & 5,6 & $0.35 \mathrm{~m} \times 0.35 \mathrm{~m}$ & $8 \phi 14$ & $\phi 8 / 80$ & \\
CD7 & 7 & $0.30 \mathrm{~m} \times 0.30 \mathrm{~m}$ & $6 \phi 14$ & $\phi 8 / 80$ & \\
\hline
\end{tabular}

Potential hinges are defined at the ends of the beams and the columns. Reinforcement at the hinges is used for evaluation of their bending moment and normal force capacities and to check whether the deformations of sections exceed the elastic limits. The structural system is pushed by a lateral load which represents the first mode until the system reaches its capacity limit. The seismic demand curve is evaluated from the spectrum of the design earthquake easily by using well-known relations between the lateral displacement and the spectral displacement and the lateral force and the spectral acceleration. The performance points of the buildings are obtained by using the capacity curve and the demand curve (Fig. 4). Performance points of the buildings are determined as shown in Fig. 5 and their characteristic parameters for each building are given in Table 10.

The codes define the target performance levels for buildings depending on the level of the seismic action and the level of the damage (inelastic deformation) which can be accepted in the buildings. Acceptance limits of each performance level are given in terms of plastic hinge rotations in ASCE-7-16, whereas in terms of the plastic hinge rotations as well as the strains of concrete and steel in the Turkish Seismic Code for Buildings. In the present numerical analysis, the acceptance limits of the plastic hinge rotations are used as given in the Turkish Seismic Code for Buildings as follows: 


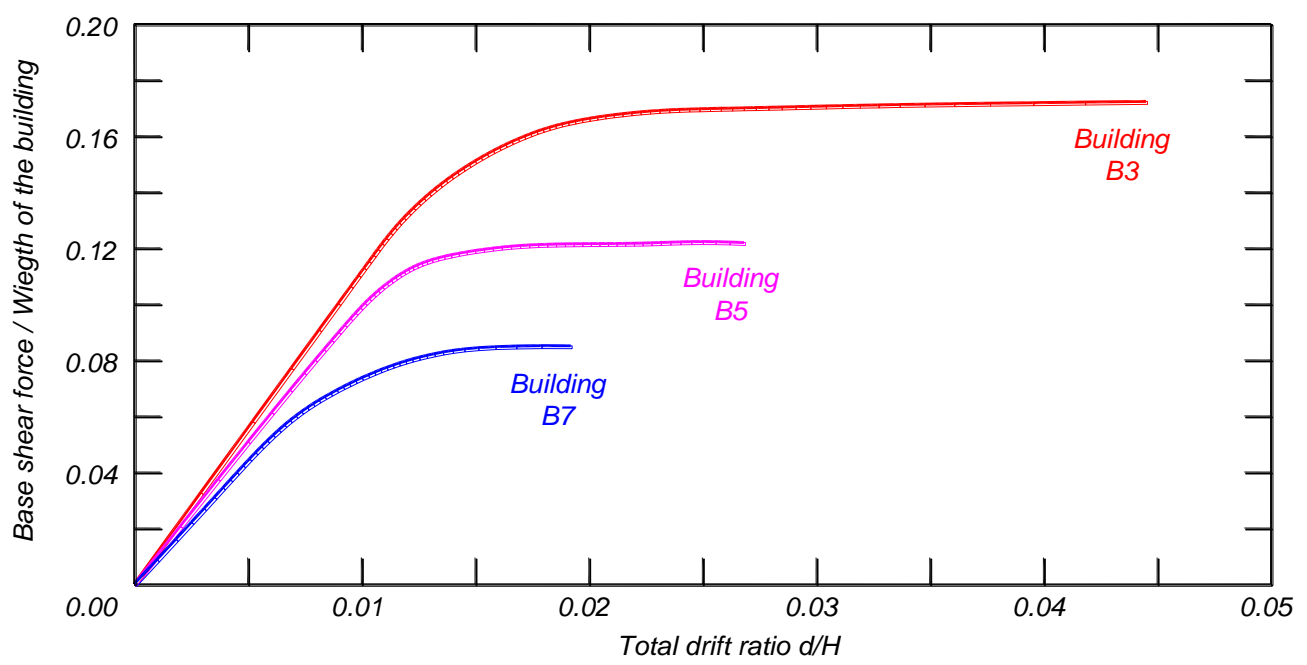

Fig. 4. Pushover curves of the buildings of various stories

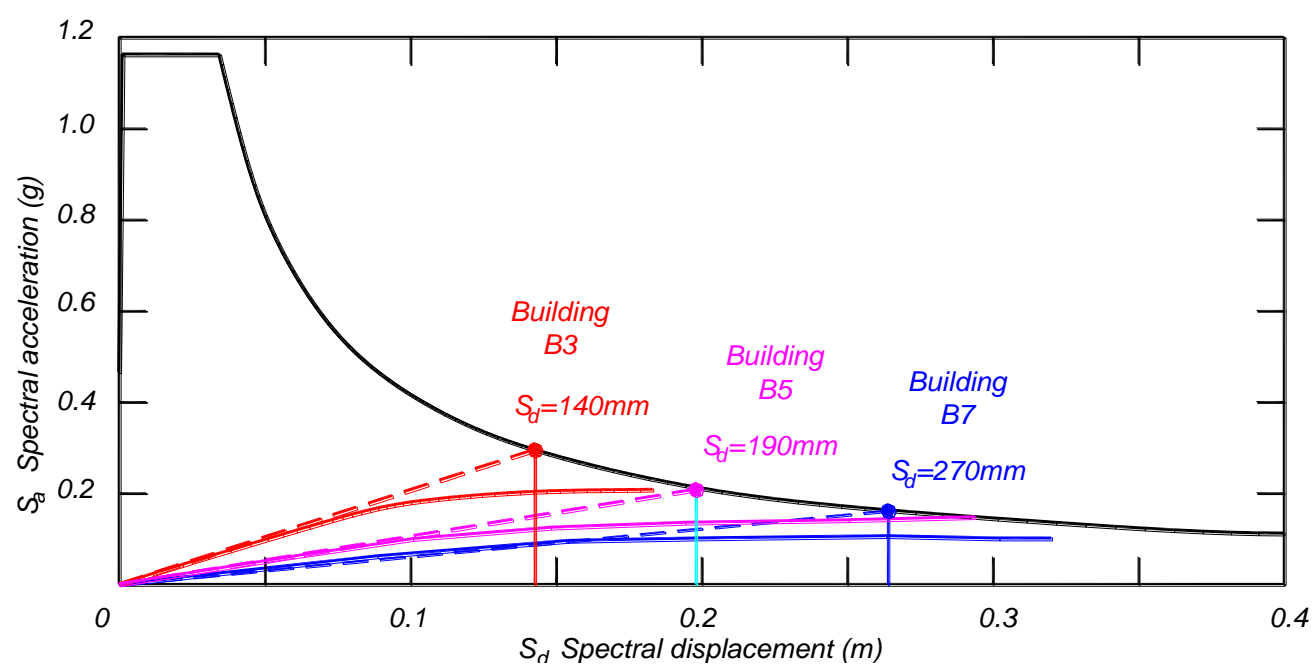

Fig. 5. Demand and capacity curves of the buildings of various stories and the corresponding performance points

Table 10. Maximum base shear and lateral drift ratio at the performance point obtained from the pushover analysis

\begin{tabular}{cccccc}
\hline \multicolumn{2}{c}{ Building B3 } & \multicolumn{2}{c}{ Building B5 } & \multicolumn{2}{c}{ Building B7 } \\
\hline $\begin{array}{c}\text { Base } \\
\text { shear/Weight }\end{array}$ & $\begin{array}{c}\text { Total drift ratio } \\
(\%)\end{array}$ & $\begin{array}{c}\text { Base } \\
\text { shear/Weight }\end{array}$ & $\begin{array}{c}\text { Total drift ratio } \\
(\%)\end{array}$ & $\begin{array}{c}\text { Base } \\
\text { shear/Weight }\end{array}$ & $\begin{array}{c}\text { Total drift ratio } \\
(\%)\end{array}$ \\
\hline 0.162 & 1.56 & 0.118 & 1.27 & 0.083 & 1.29 \\
\hline
\end{tabular}

$\theta_{p}^{(C P)}=\frac{2}{3}\left[\left(\phi_{u}-\phi_{y}\right) L_{p}\left(1-\frac{L_{p}}{2 L_{S}}\right)+4.5 \phi_{u} d_{b}\right]$ for collapse prevention

$\theta_{p}^{(L S)}=0.75 \theta_{p}^{(C P)}$ for life safety

$\theta_{p}^{(L D)}=0$ for limited damage 
where $\theta_{p}$ is the rotation of the plastic hinge, $\phi_{y}$ and $\phi_{u}$ are their yield and ultimate curvatures, $L_{p}$ and $L_{s}$ are the length of the plastic hinges and the shear span, respectively, and $d_{b}$ is the average diameter of the steel bars. Furthermore, the effective stiffnesses of the members in between end hinges are evaluated as $(E I)_{e}=M_{y} L_{s} /\left(3 \theta_{y}\right)$. Since the importance factor of the buildings is unity, the buildings are expected to satisfy the life safety performance level inherently. For each plastic hinge of the beams and the columns, the plastic rotation limits of the life safety are calculated by considering the bending moment in the case of the beams and by considering the normal forces in addition to the bending moment in the case of the columns. The last step in the performance evaluation is to check whether the plastic hinge rotations evaluated at the performance point satisfy the corresponding limits. Performance levels of the beams and the columns are evaluated depending on the inelastic deformations of the plastic hinges at the two ends by taking into account the most unfavorable one. Performance regions of the beams and the columns in each story in terms of percentages are summarized for the buildings studied in Table 11.

Table 11. Performances of the beams and the columns in each story in terms of percentages obtained from the nonlinear static (pushover) analysis

\begin{tabular}{cccccccccc}
\hline \multicolumn{1}{c}{ Beams } \\
\hline Building & Story & $\begin{array}{c}\text { Minimum } \\
\text { damage }\end{array}$ & $\begin{array}{c}\text { Marked } \\
\text { damage }\end{array}$ & $\begin{array}{c}\text { Advanced } \\
\text { damage }\end{array}$ & $\begin{array}{c}\text { Collapse } \\
\text { prevention }\end{array}$ & $\begin{array}{c}\text { Minimum } \\
\text { damage }\end{array}$ & $\begin{array}{c}\text { Marked } \\
\text { damage }\end{array}$ & $\begin{array}{c}\text { Advanced } \\
\text { damage }\end{array}$ & $\begin{array}{c}\text { Collapse } \\
\text { prevention }\end{array}$ \\
\hline $\begin{array}{c}\text { Building } \\
\text { of 3 }\end{array}$ & 3 & 100 & 0 & 0 & 0 & 38 & 37 & 25 & 0 \\
stories & 1 & 67 & 33 & 0 & 0 & 62 & 38 & 0 & 0 \\
\hline & 5 & 100 & 33 & 17 & 0 & 0 & 100 & 0 & 0 \\
Building & 4 & 100 & 0 & 0 & 0 & 100 & 0 & 0 & 0 \\
of 5 & 3 & 100 & 0 & 0 & 0 & 25 & 75 & 0 & 0 \\
stories & 2 & 58 & 17 & 25 & 0 & 100 & 0 & 0 & 0 \\
& 1 & 58 & 25 & 17 & 0 & 50 & 50 & 0 & 0 \\
\hline & 7 & 100 & 0 & 0 & 0 & 100 & 0 & 0 & 0 \\
Building & 5 & 100 & 0 & 0 & 0 & 100 & 0 & 0 & 0 \\
of 7 & 4 & 100 & 0 & 0 & 0 & 100 & 0 & 0 & 0 \\
stories & 3 & 100 & 0 & 0 & 0 & 37 & 63 & 0 & 0 \\
& 2 & 50 & 17 & 33 & 0 & 100 & 0 & 0 & 0 \\
& 1 & 50 & 17 & 33 & 0 & 0 & 100 & 0 & 0 \\
\hline
\end{tabular}

Table 12. Maximum base shears and lateral story drift ratios obtained from the nonlinear dynamic analysis

\begin{tabular}{ccccccc}
\hline \multirow{2}{*}{ Building } & $\begin{array}{c}\text { Imperial Valley, California 1979 } \\
\text { (Scaling factor 2.143) }\end{array}$ & \multicolumn{2}{c}{$\begin{array}{c}\text { El Mayor, Mexico 2010 (Scaling } \\
\text { factor 1.029) }\end{array}$} & \multicolumn{2}{c}{$\begin{array}{c}\text { Darfield, New Zealand 2010 } \\
\text { (Scaling factor 3.153) }\end{array}$} \\
\cline { 2 - 7 } & $\begin{array}{c}\text { Base } \\
\text { shear/Weight }\end{array}$ & $\begin{array}{c}\text { Total drift ratio } \\
(\%)\end{array}$ & $\begin{array}{c}\text { Base } \\
\text { shear/Weight }\end{array}$ & $\begin{array}{c}\text { Total drift ratio } \\
(\%)\end{array}$ & $\begin{array}{c}\text { Base } \\
\text { shear/Weight }\end{array}$ & $\begin{array}{c}\text { Total drift ratio } \\
(\%)\end{array}$ \\
\hline B3 & 0.181 & 1.000 & 0.177 & 1.778 & 0.169 & 1.667 \\
B5 & 0.126 & 1.067 & 0.132 & 1.400 & 0.116 & 1.133 \\
B7 & 0.086 & 0.762 & 0.097 & 1.000 & 0.084 & 0.857 \\
\hline
\end{tabular}


Table 13. Performances of the beams and the columns in each story in terms of percentages obtained from the nonlinear time domain analysis

\begin{tabular}{|c|c|c|c|c|c|c|c|c|c|}
\hline \multirow[b]{2}{*}{ Building } & \multirow[b]{2}{*}{ Earthquake } & \multicolumn{4}{|c|}{ Beams } & \multicolumn{4}{|c|}{ Columns } \\
\hline & & $\begin{array}{l}\text { Minimum } \\
\text { damage }\end{array}$ & $\begin{array}{l}\text { Marked } \\
\text { damage }\end{array}$ & $\begin{array}{c}\text { Advanced } \\
\text { damage }\end{array}$ & $\begin{array}{l}\text { Collapse } \\
\text { prevention }\end{array}$ & $\begin{array}{l}\text { Minimum } \\
\text { damage }\end{array}$ & $\begin{array}{l}\text { Marked } \\
\text { damage }\end{array}$ & $\begin{array}{c}\text { Advanced } \\
\text { damage }\end{array}$ & $\begin{array}{l}\text { Collapse } \\
\text { prevention }\end{array}$ \\
\hline \multirow{3}{*}{ B3s } & $\begin{array}{c}\text { Imperial } \\
\text { Valley }\end{array}$ & 57 & 32 & 11 & 0 & 6 & 73 & 21 & 0 \\
\hline & El Mayor & 69 & 31 & 0 & 0 & 8 & 67 & 25 & 0 \\
\hline & Darfield & 64 & 36 & 0 & 0 & 8 & 79 & 13 & 0 \\
\hline \multirow{3}{*}{ B5 } & $\begin{array}{c}\text { Imperial } \\
\text { Valley }\end{array}$ & 72 & 25 & 3 & 0 & 36 & 64 & 0 & 0 \\
\hline & El Mayor & 63 & 18 & 19 & 0 & 48 & 52 & 0 & 0 \\
\hline & Darfield & 87 & 10 & 3 & 0 & 80 & 20 & 0 & 0 \\
\hline \multirow{3}{*}{ B7 } & $\begin{array}{c}\text { Imperial } \\
\text { Valley }\end{array}$ & 79 & 18 & 3 & 0 & 63 & 37 & 0 & 0 \\
\hline & El Mayor & 68 & 24 & 8 & 0 & 55 & 45 & 0 & 0 \\
\hline & Darfield & 72 & 17 & 11 & 0 & 61 & 39 & 0 & 0 \\
\hline
\end{tabular}

\section{Nonlinear dynamic analysis of the buildings}

In the final step, nonlinear time-domain analysis is accomplished by using the same structural models of the buildings developed for the pushover analysis, by adopting the selected and scaled acceleration records, i.e., Imperial Valley, El Mayor and Darfield [11]. Maximum base shears and lateral story drift ratios and the performance regions of the beams and the columns in each story in terms of percentages for the buildings are presented in Table 12 and Table 13, respectively.Comparing the base shears of Table 3 and Table 12, the representative base shear reduction factors can be obtained. For example, for B3 building, the representative base shear reduction factor can be found as $0.133 \times 8 /$ $0.181=5.88$ by using Imperial Valley results. The other results are obtained similarly and given in Table 14. In the foregoing numerical evaluation, the base shear reduction factor.is assumed to be 8 for the linear analysis, whereas Table 14 shows that the reduction values are well below the reduction coefficients given in the codes. The ratio of the elastic displacement to the inelastic displacement is presented in the table as well. As remembered, according to the equal displacement rule, the linear and the nonlinear displacements in the buildings subjected to the same seismic record are expected to be approximately equal. When the corresponding results in Table 14 are inspected, it is difficult to claim that the equal displacement rule is satisfied. In fact, it is well-known that the equal displacement rule applies to the average of a large number of solutions, instead of single solutions. However, it is worth remembering that, in the pushover analysis, the performance point is evaluated by using this rule for single solutions. This fact may lead to a discussion on the approximation of the various evaluation processes each of which employs the equal displacement rule.

Turkish Seismic Code for Buildings states that a building can be accepted to satisfy Life Safety Performance Level provided that on each story at most $35 \%$ of the beams can exceed the Advanced Damage Zone. Furthermore, the total contribution of the columns in the Advanced Damage Zone to the shear force of the columns in each story should not exceed $20 \%$, this ratio at most $40 \%$ for the top stories. Inspection of Tables 11 and Table 13 yields that all three buildings satisfy the life safety performance as expected, because the structural system is designed accordingly by following requirements of the equivalent lateral force procedure.

The buildings are designed by taking into account the base shear of the static equivalent lateral force. The necessary sections and reinforcements of the members are determined without increasing them due to any other reason, so that additional capacity increase in the system is 
prevented. Table 15 shows a summary of the numerical results of the linear and the nonlinear analyses in terms of the base shear and the lateral displacement. The base shear capacities of the system are shown in the last column of the table evaluated by using the linear and nonlinear analyses with respect to the base of the static equivalent lateral force method. The table displays the nonlinear lateral load capacity evaluated by using the pushover analysis with respect to the design capacity. They are $1.641,1.573$ and 1.383 for the buildings of three, five and seven stories, respectively (when the results are normalized 1.187, 1.137 and 1.000). The nonlinear timedomain analysis shows that the three-, five- and seven-story buildings have relative capacities of 1.834, 1.680 and 1.433, (for Imperial Valley, when the results are normalized 1.280, 1.172 and 1.000), 1.783, 1760 and 1.067, (for El Mayor, when the results are normalized $1.671,1.648$ and 1.000) and
1.712, 1547 and 1.400, (for Darfield, when the results are normalized $1.223,1.105$ and 1.000).

The seismic codes assume inherently that the structural systems designed by using the linear methods, i.e., the static equivalent lateral force method, the modal response spectrum method and the time domain analysis, by adopting a response modification factor exhibit the same level of inelastic lateral load capacity. In other words, the response modification factor depends on the structural systems only. The above results show that the low-rise buildings designed by using the linear methods have relatively larger lateral load capacity compared to the buildings with a larger number of stories. This conclusion can be stated as follows as well: The response modification factor which is assumed to be dependent on the structural system also depends on the number of the stories. This factor is larger in low-rise buildings than in medium-rise buildings.

Table 14. Numerical results of the linear time domain analysis

\begin{tabular}{ccccccc}
\hline \multirow{2}{*}{ Building } & $\begin{array}{c}\text { Imperial Valley, California 1979 } \\
\text { (Scaling factor 2.143) }\end{array}$ & \multicolumn{2}{c}{$\begin{array}{c}\text { El Mayor, Mexico 2010 } \\
\text { (Scaling factor 1.029) }\end{array}$} & \multicolumn{2}{c}{$\begin{array}{c}\text { Darfield, New Zealand 2010 } \\
\text { (Scaling factor 3.153) }\end{array}$} \\
\cline { 2 - 7 } & $\begin{array}{c}\text { Base shear } \\
\text { reduction } \\
\text { factor }\end{array}$ & $\begin{array}{c}\text { Ratio of elastic } \\
\text { to inelastic } \\
\text { displacements }\end{array}$ & $\begin{array}{c}\text { Base shear } \\
\text { reduction } \\
\text { factor }\end{array}$ & $\begin{array}{c}\text { Ratio of elastic } \\
\text { to inelastic } \\
\text { displacements }\end{array}$ & $\begin{array}{c}\text { Base shear } \\
\text { reduction } \\
\text { factor }\end{array}$ & $\begin{array}{c}\text { Ratio of elastic } \\
\text { to inelastic } \\
\text { displacements }\end{array}$ \\
\hline B3 & 5.88 & 1.19 & 4.20 & 0.52 & 2.89 & 0.34 \\
B5 & 5.21 & 0.63 & 3.64 & 0.32 & 5.59 & 0.52 \\
B7 & 3.35 & 0.54 & 5.28 & 0.70 & 7.71 & 1.16 \\
\hline
\end{tabular}

Table 15. Comparison of the results of the linear and the nonlinear analyses for the buildings

\begin{tabular}{|c|c|c|c|c|c|}
\hline Building & & Analysis & $\begin{array}{c}\text { Base } \\
\text { shear/ } \\
\text { Weight }\end{array}$ & $\begin{array}{l}\text { Total drift } \\
\text { ratio } \\
(\%)\end{array}$ & $\begin{array}{c}\text { Base shear with respects } \\
\text { to that of the static } \\
\text { equivalent lateral force } \\
\text { method }\end{array}$ \\
\hline \multirow{7}{*}{ B3 } & \multirow{6}{*}{$\begin{array}{l}\text { Linear } \\
\text { methods }\end{array}$} & Static equivalent lateral force method & 0.0987 & 0.756 & 1.000 \\
\hline & & Modal response spectrum method & 0.0841 & 0.773 & 0.852 \\
\hline & & Time domain analysis & & & \\
\hline & & Imperial Valley & 0.133 & 1.189 & 1.348 \\
\hline & & El Mayor & 0.093 & 0.918 & 0.942 \\
\hline & & Darfield & 0.061 & 0.573 & 0.618 \\
\hline & $\begin{array}{l}\text { Nonlinear } \\
\text { methods }\end{array}$ & Pushover analysis & 0.162 & 1.556 & 1.641 \\
\hline
\end{tabular}


Table 15. Continued

\begin{tabular}{|c|c|c|c|c|c|}
\hline Building & & Analysis & $\begin{array}{c}\text { Base } \\
\text { shear/ } \\
\text { Weight }\end{array}$ & $\begin{array}{l}\text { Total drift } \\
\text { ratio } \\
(\%)\end{array}$ & $\begin{array}{c}\text { Base shear with respects } \\
\text { to that of the static } \\
\text { equivalent lateral force } \\
\text { method }\end{array}$ \\
\hline \multirow{4}{*}{ B3 } & & Time domain analysis & & & \\
\hline & & Imperial Valley & 0.181 & 1.000 & 1.834 \\
\hline & & El Mayor & 0.177 & 1.778 & 1.793 \\
\hline & & Darfield & 0.169 & 1.667 & 1.712 \\
\hline \multirow{11}{*}{ B5 } & \multirow{6}{*}{$\begin{array}{l}\text { Linear } \\
\text { methods }\end{array}$} & Static equivalent lateral force method & 0.0750 & 0.656 & 1.000 \\
\hline & & Modal response spectrum method & 0.0644 & 0.540 & 0.859 \\
\hline & & Time domain analysis & & & \\
\hline & & Imperial Valley & 0.082 & 0.675 & 1.093 \\
\hline & & El Mayor & 0.060 & 0.449 & 0.800 \\
\hline & & Darfield & 0.081 & 0.593 & 1.080 \\
\hline & \multirow{5}{*}{$\begin{array}{l}\text { Nonlinear } \\
\text { methods }\end{array}$} & Pushover analysis & 0.118 & 1.267 & 1.573 \\
\hline & & Time domain analysis & & & \\
\hline & & Imperial Valley & 0.126 & 1.067 & 1.680 \\
\hline & & El Mayor & 0.132 & 1.400 & 1.760 \\
\hline & & Darfield & 0.116 & 1.133 & 1.547 \\
\hline \multirow{11}{*}{ B7 } & \multirow{6}{*}{$\begin{array}{l}\text { Linear } \\
\text { methods }\end{array}$} & Static equivalent lateral force method & 0.0600 & 0.762 & 1.000 \\
\hline & & Modal response spectrum method & 0.0513 & 0.606 & 0.855 \\
\hline & & Time domain analysis & & & \\
\hline & & Imperial Valley & 0.036 & 0.413 & 0.600 \\
\hline & & El Mayor & 0.064 & 0.698 & 1.067 \\
\hline & & Darfield & 0.081 & 0.990 & 1.350 \\
\hline & \multirow{5}{*}{$\begin{array}{l}\text { Nonlinear } \\
\text { methods }\end{array}$} & Pushover analysis & 0.083 & 1.286 & 1.383 \\
\hline & & Time domain analysis & & & \\
\hline & & Imperial Valley & 0.086 & 0.762 & 1.433 \\
\hline & & El Mayor & 0.097 & 1.000 & 1.667 \\
\hline & & Darfield & 0.084 & 0.857 & 1.400 \\
\hline
\end{tabular}

\section{Conclusions}

In the design of buildings under seismic loads, the static equivalent lateral force method is preferred for many regular structures where the first mode is dominant in the seismic behavior. On other hand, the linear analyses, such as the modal response spectrum method and the time domain analysis are used widely, as well. In these methods, the nonlinear behavior of the structural system, i.e., the increase in the capacity of the system and the decrease in the demand of the earthquake, is taken into account by employing the earthquake load reduction coefficient, in other word, the behavior modification coefficient. Furthermore, the codes assume implicitly that the structural systems designed accordingly exhibit the same level of inelastic deformation, i.e., the controlled damage state. In this study, this implicit acceptance is investigated by considering the buildings of three, five and seven stories. They are analyzed and designed by satisfying the bare minimum requirements of the static equivalent lateral force 
method and the ultimate limit state design method. Their lateral load capacities are evaluated by using the nonlinear methods and compared to the base shear of the static equivalent lateral force method. Based on the obtained numerical results, the following conclusions can be drawn:

a. The numerical results show that the ratio of the nonlinear load capacity to the reduced equivalent seismic load depends on the number of the stories of the buildings. The buildings with a low number of stories have relatively larger lateral load capacity with respect to the reduced seismic load than the medium-rise buildings.

b. Since the nonlinear analysis goes beyond the elastic region and considers the inelastic behavior of the system, the capacity of the system increases. On the other hand, the inelastic behavior causes the structural system to be soften and become easily deformable. These two facts are taken into account by using the seismic load reduction factor. The analysis shows that this factor depends on the number of stories, which is not considered in the codes.

c. It is worth noting that to take advantage of larger seismic load reduction factors, the system must have adequate ductility that supports the growing inelastic behavior and the resulting inelastic deformations must be acceptable.

\section{Declaration of conflicting interests}

The author(s) declared no potential conflicts of interest with respect to the research, authorship, and/or publication of this article.

\section{References}

[1] Atmaca B, Demir S, Günaydın M, Altunışık AC, Hüsem M, Ateş Ş, Adanur S, Angın Z (2020) Lessons learned from the past earthquakes on building performance in Turkey. Journal of Structural Engineering and Applied Mechanics 3(2): 61-84.

[2] Carvalho G, Bento R, Bhatt C (2013) Nonlinear static and dynamic analyses of reinforced concrete buildings-comparison of different modelling approaches. Earthquakes and Structures 4(5): 451470.
[3] Naderpour H, Mirrashid M (2020) A novel definition of damage states for structural elements in framed reinforced concrete buildings. Journal of Building Engineering 32: 101479.

[4] Zou XK, Chan CM (2005) Optimal seismic performance-based design of reinforced concrete buildings using nonlinear pushover analysis. Engineering Structures 27: 1289-1302.

[5] Liu Y, Kuang JS, Huang Q (2018) Modified spectrum-based pushover analysis for estimating seismic demand of dual wall-frame systems. Engineering Structures 165: 302-314.

[6] Liua Y, Kuang JS, Huang Q, Guo Z, Wang X (2020) Spectrum-based pushover analysis for the quick seismic demand estimation of reinforced concrete shear walls. Structures 27: 1490-1500.

[7] Yön B, Calayır Y (2015) The soil effect on the seismic behaviour of reinforced concrete buildings. Earthquakes and Structures 8(1): 133-152.

[8] Yön B, Calayır Y (2014) Effects of confinement reinforcement and concrete strength on nonlinear behaviour of RC buildings. Computers and Concrete 14(3): 279-297.

[9] Macedo L, Silva A, Castro JM (2019) A more rational selection of the behaviour factor for seismic design according to Eurocode 8 . Engineering Structures 188: 69-86.

[10] Sanchez-Ricart L (2020) Reduction factors in seismic codes: On the components to be taken into account for design purposes. Georisk 4 (4): 208229.

[11] Melani A, Khare RK, Dhakal RP, Mander JB (2016) Seismic risk assessment of low-rise RC frame structure. Structures 5: 13-22.

[12] Uva G, Porco F, Fiore A, Ruggieri S (2018) Effects in conventional nonlinear static analysis: Evaluation of control node position. Structures 13: 178-192.

[13] Salimbahrami SR, Gholhaki M (2019) Effects of higher modes and degrees of freedom (DOF) on strength reduction factor in reinforced concrete frames equipped with steel plate shear wall. Structures 19: 234-247.

[14] Lu Y, Hajirasouliha I, Marshall AM (2014) Seismic strength reduction factor for single and multi-story shear buildings considering soil-structure interaction. Second European Conference on Earthquake Engineering and Seismology, Istanbul, August 25-29.

[15] Rao PPV, Gupta LM (2016) Effect of Seismic Zone and Story Height on Response Reduction Factor for 
SMRF Designed According to IS 1893 (Part-1): 2002. Journal of the Institution of Engineers (India): Series A 97(4): 367-383.

[16] Turkish Seismic Building Code (2018) Disaster and Emergency Management Presidency, Ankara.

[17] ASCE/SEI 7-16 (2016) Minimum Design Loads for Building and other Structures. American Society of Civil Engineers, Reston, VA.
[18] SAP2000 v.20 Computers and Structures Inc., Berkeley.

[19] PEER Ground Motion Database, Pacific Earthquake Engineering Research Center 2020.

[20] Seismomatch v.2.0.0. SeismoSoft, Pavia, Italy. 